\title{
STUDY OF IOP AND REFRACTIVE ERRORS IN VARIOUS AGE GROUPS
}

Kavita Patil ${ }^{1}$, Pranathi Kura² ${ }^{2}$ Shwetha Mangalesh ${ }^{3}$

\section{HOW TO CITE THIS ARTICLE:}

Kavita Patil, Pranathi Kura, Shwetha Mangalesh. "Study of IOP and Refractive Errors in various age groups". Journal of Evolution of Medical and Dental Sciences 2014; Vol. 3, Issue 06, February 10; Page: 1394-1400, DOI: $10.14260 /$ jemds/2014/1997

ABSTRACT: INTRODUCTION: Studies have shown that myopic subjects have a two to threefold increased risk of glaucoma compared with that of nonmyopic subjects. The age and sex of an individual with refractive error might also play a major role in altered IOP and thereby added risk factor to develop glaucoma in future. MATERIAL \& METHODS: 100 cases (50-myopia and 50hypermetropia) and 100 controls were examined for intraocular pressure using the Goldmann's Applanation Tonometer, slit lamp mounted. RESULTS: In the 35 to 40 year age group, males with myopia in the right eye, $60 \%$ showed higher IOP value ranging between 19 to $20 \mathrm{mmHg}$ when compared to control, whereas the males with myopia, in the left eye, did not show higher IOP in any of the age groups. In case of right eyed myopic females of 25 to 30 and 30 to 35 years age groups the mean IOP was found to be higher i.e. 17.7 and 18 respectively. The mean IOP value in right as well as the left eye in hypermetropic males does not show deviation from that of controls of all the age groups, whereas hypermetropic females of the age group of 30 to 35 shows lower mean IOP value as 10.8 and $10.3 \mathrm{Hg} \mathrm{mm}$ respectively in the right and the left eye. CONCLUSION: The myopic females of 25-30 years and myopic males of 35-40 years, in the right eye, with higher IOP are prone to develop glaucoma. Further the elevated IOP among the myopics can be used as clue for higher risk of Glaucoma in future.

KEYWORDS: Intraocular Pressure, Myopia, Hypermetropia, Glaucoma.

INTRODUCTION: Glaucoma is a disease of the optic nerve produced by degeneration of the retinal ganglion cells. This glaucomatous optic neuropathy is characterized by atrophy of the optic disk and progressive deterioration of visual field. The role of intraocular pressure in the pathogenesis of glaucoma has been controversial. Studies have unequivocally confirmed that individuals with glaucoma have, on an average, higher levels of intraocular pressure. Intraocular pressure (IOP) is one of several factors implicated in the pathogenesis of myopia. ${ }^{1}$ Elevated IOP is hypothesized to impose scleral stress and creep, resulting in axial elongation with scleral stretch. ${ }^{2}$ In the past, glaucoma in myopic eye was usually missed until it had reached an advanced stage. Several reasons had contributed to this such as difficulty in the interpretation of changes associated with glaucoma. With the advancement of the technique of tonography, the problem of diagnosing glaucoma entered a new field. It becomes important to know whether altered pressure of the aqueous has any relation with the refractive errors. Most population based studies in adults have however found significant relations between IOP and refractive error ${ }^{3,4}$ or myopia. ${ }^{5,6}$ it was also found out that the mean IOP increased gradually from $14.19 \mathrm{~mm} \mathrm{Hg}$ in hypermetropes to $16.00 \mathrm{~mm} \mathrm{Hg}$ among high myopes. ${ }^{7} \mathrm{The}$ progression of myopia was studied by Jensen $\mathrm{H}$. in 49 children aged 9-12 years, over a period of 2 years. The results were supported by ultrasound measurement of the axial length. The author recommends that measurement of IOP should be included in the design of studies of myopia progression since the individuals with more risk of developing higher degrees of myopia have a high 
IOP. ${ }^{8}$ The question is that, is there any relation between age and sex of a myopic and Hypermetropic patient to have higher IOP which could have given a clue for higher risk of Glaucoma? Hence, the aim and objective of this study is to correlate the intraocular pressure and the refractive errors in various age groups.

MATERIALS AND METHODS: The study is a Case Control Study conducted in the Teaching Hospital of Raichur Institute of Medical Sciences100 cases (50-myopia and 50-hypermetropia) and 100 controls were chosen. The cases constituted those with refractive errors between the age group of 15-40 years. Patients with pre-existing ocular pathology, systemic diseases with ocular manifestations and those who did not consent to undergo the procedure were excluded from the study. The cases and controls were age and sex matched.

All cases and controls were first screened for the presence of refractive errors using Snellen's Chart for Visual Acuity. A Snellen's chart is generally used to determine the unaided visual acuity without spectacles. Improvement in visual acuity by 2 or more lines on the Snellen's chart when looking through the pin hole was regarded as an indication of refractive error. ${ }^{9}$ They were subject to Intraocular Pressure Assessment using Goldmann's Applanation Tonometer.10,11 All patients were anaesthetized pre procedure with paracaine $\mathrm{HCl}$ and fluorescein sodium strips were used to stain the eye. ${ }^{12}$ Post Procedure Antibiotic drops were used. The values in both the eyes of each patient were recorded. The data collected was analyzed using SPSS version 16.1.

RESULTS: A total number of 100 cases and 100 controls were included in the study. Among the cases 50 were each Myopic and Hypermetropic.

The highest number of myopia cases was seen in the age group of 20 to 25 (44\%) as shown in chart no. 1. Of this a higher frequency of myopia (56\%) was found in the age group of 20 to 25 years in females when compared to that of males (31\%) specifically in the age group 15 to 20 years as indicated in table no $1 \mathrm{~b}$ and chart no. 2 .

The highest number (40\%) of hypermetropic cases was seen in the age group of 35 to 40 . The hypermetropic condition is found to be more prevalent in females of all the age group (from 15 to 40) when compared to males where prevalence was observed in the age group of 35 to 40 specifically as shown in table no. 2 and chart no 3.

Table no. 3 reveals that $60 \%$ myopic males showed a higher mean IOP value, above the mean IOP of $15.8 \mathrm{mmHg}$ in the right eye and more than that of control in the age group 35 - 40 years. Whereas in the left eye, an IOP ranging between 13.3 to $15 \mathrm{mmHg}$ was recorded, this is similar to that of the control group.

The study revealed that in the right eye of myopic females between 25 and 30 and 30 and 35 years age groups have higher mean IOP i.e. 17.7 and $18 \mathrm{mmHg}$ respectively. Whereas in case of control the mean IOP was found to be in the range of 10.9 to $14.7 \mathrm{mmHg}$ in all the age groups. The left eye showed a similar observation to that of right eye with respect to IOP varying between 16 to 18 mmHg in the age group of 25 to 30 and 30 to 35 (Table no. 4).

The hypermetropic observations shown in table no. 5 indicates the mean IOP is as least as $12.2 \mathrm{mmHg}$ in the right eye of males between 30 to 35 years which is lesser than the standard mean IOP i.e. $12.9 \mathrm{mmHg}$. Also there is no significant deviation from control observed in this age group. 
With respect to left eye it was observed that the mean IOP value for the age group between 30 to 35 was $11.8 \mathrm{mmHg}$ which is lesser than the mean value of control (13 $\mathrm{mmHg}$ ).

In Hypermetropic females as shown in table no. 6, the right eye showed a mean IOP value as $10.8 \mathrm{mmHg}$, which is lesser than the mean IOP value of control i.e.12.5 $\mathrm{mmHg}$ in the age group of 30 to 35 years. The left eye revealed a mean IOP value as $10.3 \mathrm{mmHg}$ in the age group of 30 to 35 when compared to the mean IOP of all age as $11.6 \mathrm{mmHg}$ and the mean IOP value in control which is found to be $13.4 \mathrm{mmHg}$.

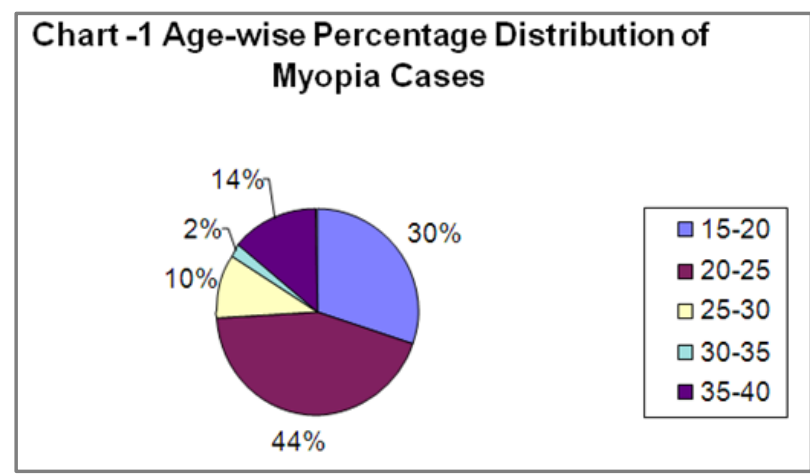

\begin{tabular}{|c|c|c|c|c|c|}
\hline \multirow{3}{*}{ Age } & \multicolumn{4}{|c|}{ Case } & \multirow{3}{*}{ Total } \\
\hline & \multicolumn{2}{|c|}{ Male } & \multicolumn{2}{|c|}{ Female } & \\
\hline & No & $\%$ & No & $\%$ & \\
\hline $15-20$ & 06 & 38 & 09 & 26 & $15(30 \%)$ \\
\hline $20-25$ & 03 & 19 & 19 & 56 & $22(44 \%)$ \\
\hline $25-30$ & 02 & 13 & 03 & 09 & $05(10 \%)$ \\
\hline $30-35$ & 00 & 00 & 01 & 03 & $01(02 \%)$ \\
\hline $35-40$ & 05 & 31 & 02 & 06 & 07 (14\%) \\
\hline Total & 16 & 100 & 34 & 100 & $50(100 \%)$ \\
\hline
\end{tabular}

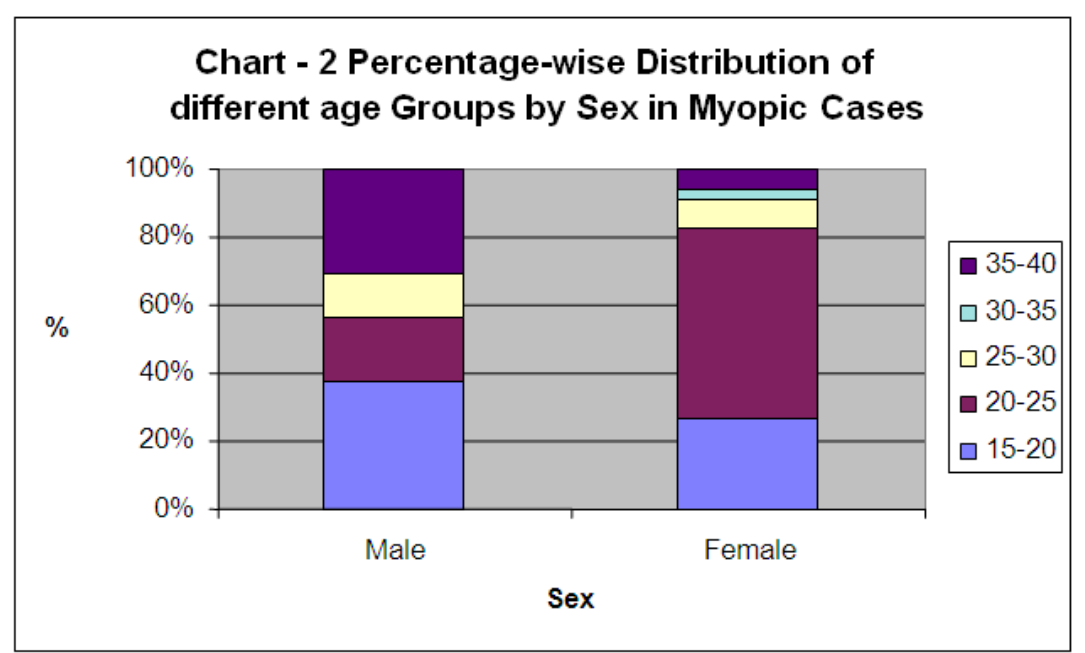




\begin{tabular}{|c|c|c|c|c|c|}
\hline \multirow{2}{*}{ Age } & \multicolumn{4}{|c|}{ Case } & \multirow{2}{*}{ Total } \\
\cline { 2 - 5 } & \multicolumn{2}{|c|}{ Male } & \multicolumn{2}{c|}{ Female } & \multirow{2}{*}{} \\
\cline { 2 - 5 } & No & $\mathbf{\%}$ & No & $\mathbf{\%}$ & \\
\hline $15-20$ & 04 & 19 & 06 & 21 & $10(20 \%)$ \\
\hline $20-25$ & 02 & 10 & 05 & 17 & $07(14 \%)$ \\
\hline $25-30$ & 01 & 05 & 02 & 07 & $03(06 \%)$ \\
\hline $30-35$ & 06 & 29 & 04 & 14 & $10(20 \%)$ \\
\hline $35-40$ & 08 & 38 & 12 & 41 & $20(40 \%)$ \\
\hline Total & 21 & 100 & 29 & 100 & $50(100 \%)$ \\
\hline \hline
\end{tabular}

Table 2: Age \& Sex Profile of Hypermetropia case

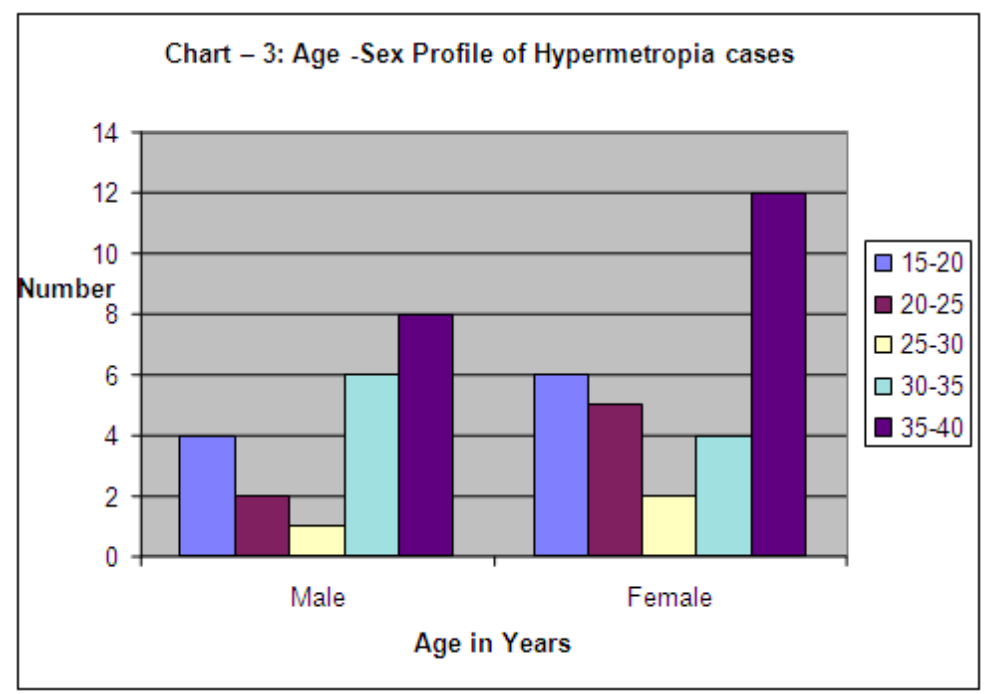

\begin{tabular}{|c|c|c|c|c|c|c|c|}
\hline \multirow{2}{*}{$\begin{array}{l}\text { Age } \\
\text { Group }\end{array}$} & \multirow{2}{*}{$\begin{array}{c}\text { No. of } \\
\text { Observation }\end{array}$} & \multicolumn{2}{|c|}{ Mean IOP Value } & \multicolumn{2}{|c|}{ Myopia (No. \& \%) } & \multicolumn{2}{|c|}{ Control (No. \& \%) } \\
\hline & & Myopia & Control & $\begin{array}{c}<\text { Mean } \\
\text { IOP Value }\end{array}$ & $\begin{array}{c}>=\text { Mean } \\
\text { IOP Value }\end{array}$ & $\begin{array}{c}<\text { Mean } \\
\text { IOP Value }\end{array}$ & $\begin{array}{l}>=\text { Mean } \\
\text { IOP Value }\end{array}$ \\
\hline \multirow{2}{*}{$15-20$} & \multirow{2}{*}{6} & 14.5 & 13.5 & $3(50 \%)$ & $3(50 \%)$ & $2(33 \%)$ & $4(67 \%)$ \\
\hline & & $(14.5)$ & $(13.5)$ & $3(50 \%)$ & $3(50 \%)$ & $2(33 \%)$ & $4(67 \%)$ \\
\hline \multirow{2}{*}{$20-25$} & \multirow{2}{*}{3} & 12.7 & 12.7 & $2(67 \%)$ & $1(33 \%)$ & $2(67 \%)$ & $1(33 \%)$ \\
\hline & & $(13.30)$ & $(12.3)$ & $2(67 \%)$ & $1(33 \%)$ & $1(33 \%)$ & $2(67 \%)$ \\
\hline \multirow{2}{*}{$25-30$} & \multirow{2}{*}{2} & 16.5 & 11 & $1(50 \%)$ & $1(50 \%)$ & $1(50 \%)$ & $1(50 \%)$ \\
\hline & & $(15.0)$ & $(13.0)$ & $1(50 \%)$ & $1(50 \%)$ & $1(50 \%)$ & $1(50 \%)$ \\
\hline \multirow{2}{*}{$30-35$} & \multirow[b]{2}{*}{0} & 0 & 0 & 0 & 0 & 0 & 0 \\
\hline & & $(0)$ & $(0)$ & $(0)$ & $(0)$ & $(0)$ & $(0)$ \\
\hline \multirow{2}{*}{$35-40$} & \multirow{2}{*}{5} & 15.8 & 13.2 & $2(40 \%)$ & $3(60 \%)$ & $3(60 \%)$ & $2(40 \%)$ \\
\hline & & $(13.6)$ & $(13.2)$ & $3(60 \%)$ & $2(40 \%)$ & $3(60 \%)$ & $2(40 \%)$ \\
\hline
\end{tabular}

Table 3: Statistical Summary IOP In Myopia Male: Right Eye \& Left Eye 
ORIGINAL ARTICLE

\begin{tabular}{|c|c|c|c|c|c|c|c|}
\hline \multirow{2}{*}{$\begin{array}{l}\text { Age } \\
\text { Group }\end{array}$} & \multirow{2}{*}{$\begin{array}{c}\text { No. of } \\
\text { Observation }\end{array}$} & \multicolumn{2}{|c|}{ Mean IOP Value } & \multicolumn{2}{|c|}{$\begin{array}{c}\text { Myopia Cases (No. \& } \\
\%)\end{array}$} & \multicolumn{2}{|c|}{$\begin{array}{c}\text { Control Cases (No. \& } \\
\%)\end{array}$} \\
\hline & & $\begin{array}{c}\text { Myopia } \\
\text { Cases }\end{array}$ & $\begin{array}{c}\text { Control } \\
\text { Cases }\end{array}$ & $\begin{array}{c}<\text { Mean } \\
\text { IOP } \\
\text { Value }\end{array}$ & $\begin{array}{l}>=\text { Mean } \\
\text { IOP Value }\end{array}$ & $\begin{array}{c}<\text { Mean } \\
\text { IOP } \\
\text { Value }\end{array}$ & $\begin{array}{l}\text { > = Mean } \\
\text { IOP Value }\end{array}$ \\
\hline $15-20$ & 9 & $\begin{array}{c}15.1 \\
(12.3)\end{array}$ & $\begin{array}{c}10.9 \\
(11.6)\end{array}$ & $\begin{array}{l}4(44 \%) \\
5(55 \%)\end{array}$ & $\begin{array}{l}5(55 \%) \\
4(44 \%)\end{array}$ & $\begin{array}{l}8(89 \%) \\
4(44 \%)\end{array}$ & $\begin{array}{l}1(11 \%) \\
5(55 \%)\end{array}$ \\
\hline $20-25$ & 19 & $\begin{array}{c}13.8 \\
(13.6) \\
\end{array}$ & $\begin{array}{c}13 \\
(13.7) \\
\end{array}$ & $\begin{array}{c}9(47 \%) \\
12(62 \%)\end{array}$ & $\begin{array}{c}10(53 \%) \\
7(38 \%)\end{array}$ & $\begin{array}{l}10(53 \%) \\
14(74 \%)\end{array}$ & $\begin{array}{l}9(47 \%) \\
5(26 \%) \\
\end{array}$ \\
\hline $25-30$ & 3 & $\begin{array}{c}17.7 \\
(18.0) \\
\end{array}$ & $\begin{array}{c}14.7 \\
(15.0) \\
\end{array}$ & $\begin{array}{c}1(33 \%) \\
0(0 \%) \\
\end{array}$ & $\begin{array}{c}2(67 \%) \\
3(100 \%) \\
\end{array}$ & $\begin{array}{l}1(33 \%) \\
1(33 \%) \\
\end{array}$ & $\begin{array}{l}2(67 \%) \\
2(67 \%) \\
\end{array}$ \\
\hline $30-35$ & 1 & $\begin{array}{c}18.0 \\
(16.0)\end{array}$ & $\begin{array}{c}13 \\
(10.0)\end{array}$ & $\begin{array}{l}0(0 \%) \\
0(0 \%)\end{array}$ & $\begin{array}{l}1(100 \%) \\
1(100 \%)\end{array}$ & $\begin{array}{l}0(0 \%) \\
0(0 \%)\end{array}$ & $\begin{array}{l}1(100 \%) \\
1(100 \%)\end{array}$ \\
\hline $35-40$ & 2 & $\begin{array}{c}13.5 \\
(15.0)\end{array}$ & $\begin{array}{c}13 \\
(13.5)\end{array}$ & $\begin{array}{l}1(50 \%) \\
1(50 \%)\end{array}$ & $\begin{array}{l}1(50 \%) \\
1(50 \%)\end{array}$ & $\begin{array}{l}1(50 \%) \\
1(50 \%)\end{array}$ & $\begin{array}{l}1(50 \%) \\
1(50 \%)\end{array}$ \\
\hline
\end{tabular}

Table 4: Statistical Summary - Myopia Cases Female: Right Eye and Left Eye

\begin{tabular}{|c|c|c|c|c|c|c|c|}
\hline \multirow{2}{*}{$\begin{array}{c}\text { Age } \\
\text { Group }\end{array}$} & \multirow{2}{*}{$\begin{array}{c}\text { No. of } \\
\text { Observation }\end{array}$} & \multicolumn{2}{|c|}{ Mean IOP Value } & \multicolumn{2}{|c|}{$\begin{array}{c}\text { Myopia Cases } \\
\text { (No. \& \%) }\end{array}$} & \multicolumn{2}{|c|}{$\begin{array}{c}\text { Control Cases } \\
\text { (No. \& \%) }\end{array}$} \\
\hline & & $\begin{array}{c}\text { Myopia } \\
\text { Cases }\end{array}$ & $\begin{array}{c}\text { Control } \\
\text { Cases }\end{array}$ & $\begin{array}{c}<\text { Mean } \\
\text { IOP Value }\end{array}$ & $\begin{array}{l}\text { > = Mean } \\
\text { IOP Value }\end{array}$ & $\begin{array}{c}<\text { Mean } \\
\text { IOP Value }\end{array}$ & $\begin{array}{l}\text { > = Mean } \\
\text { IOP Value }\end{array}$ \\
\hline \multirow{2}{*}{$15-20$} & \multirow{2}{*}{4} & 12.5 & 12.5 & $2(50 \%)$ & $2(50 \%)$ & $1(25 \%)$ & $3(75 \%)$ \\
\hline & & $(12.3)$ & (11) & $1(25 \%)$ & $3(75 \%)$ & $1(25 \%)$ & $3(75 \%)$ \\
\hline \multirow{2}{*}{$20-25$} & \multirow{2}{*}{2} & 13.5 & 12.5 & $1(50 \%)$ & $1(50 \%)$ & $1(50 \%)$ & $1(50 \%)$ \\
\hline & & $(14.5)$ & $(12)$ & $1(50 \%)$ & $1(50 \%)$ & $1(50 \%)$ & $1(50 \%)$ \\
\hline \multirow{2}{*}{$25-30$} & \multirow{2}{*}{1} & 16.0 & 15.0 & $0(0 \%)$ & $1(100 \%)$ & $0(0 \%)$ & $1(100 \%)$ \\
\hline & & $(12.0)$ & $(12)$ & $0(0 \%)$ & $1(100 \%)$ & $0(0 \%)$ & $1(100 \%)$ \\
\hline \multirow{2}{*}{$30-35$} & \multirow{2}{*}{6} & 12.2 & 11.8 & $5(83 \%)$ & $1(17 \%)$ & $3(50 \%)$ & $3(50 \%)$ \\
\hline & & $(11.8)$ & (13) & $2(33 \%)$ & $4(67 \%)$ & $4(67 \%)$ & $2(33 \%)$ \\
\hline \multirow{2}{*}{$35-40$} & \multirow[b]{2}{*}{8} & 13.1 & 11.9 & $5(63 \%)$ & $3(37 \%)$ & $6(75 \%)$ & $2(25 \%)$ \\
\hline & & $(13.4)$ & $(13.5)$ & $5(63 \%)$ & $3(37 \%)$ & $7(89 \%)$ & $1(11 \%)$ \\
\hline
\end{tabular}

Table 5: Statistical Summary - Hypermetropia Cases Male: Right Eye and Left Eye

\begin{tabular}{|c|c|c|c|c|c|c|c|}
\hline \multirow[b]{2}{*}{$\begin{array}{c}\text { Age } \\
\text { Group }\end{array}$} & \multirow[b]{2}{*}{$\begin{array}{c}\text { No. of } \\
\text { Observation }\end{array}$} & \multicolumn{2}{|c|}{ Mean IOP Value } & \multicolumn{2}{|c|}{$\begin{array}{c}\text { Myopia Cases } \\
\text { (No. \& \%) }\end{array}$} & \multicolumn{2}{|c|}{$\begin{array}{c}\text { Control Cases } \\
\text { (No. \& \%) }\end{array}$} \\
\hline & & $\begin{array}{c}\text { Myopia } \\
\text { Cases }\end{array}$ & $\begin{array}{c}\text { Control } \\
\text { Cases }\end{array}$ & $\begin{array}{c}\text { < Mean } \\
\text { IOP } \\
\text { Value }\end{array}$ & $\begin{array}{l}\text { > = Mean } \\
\text { IOP Value }\end{array}$ & $\begin{array}{c}<\text { Mean } \\
\text { IOP } \\
\text { Value }\end{array}$ & $\begin{array}{l}\text { > Mean } \\
\text { IOP Value }\end{array}$ \\
\hline \multirow{2}{*}{$15-20$} & \multirow[b]{2}{*}{6} & 12.2 & 14.3 & $5(84 \%)$ & $1(16 \%)$ & $1(16 \%)$ & $5(84 \%)$ \\
\hline & & $(11.0)$ & $(13.2)$ & $3(50 \%)$ & $3(50 \%)$ & $3(50 \%)$ & $3(50 \%)$ \\
\hline \multirow{2}{*}{$20-25$} & \multirow{2}{*}{5} & 11.6 & 13.2 & $4(80 \%)$ & $1(20 \%)$ & $3(60 \%)$ & $2(40 \%)$ \\
\hline & & $(12.0)$ & $(12.8)$ & $4(80 \%)$ & $1(20 \%)$ & $3(60 \%)$ & $2(40 \%)$ \\
\hline
\end{tabular}




\begin{tabular}{|c|c|c|c|c|c|c|c|}
\hline $25-30$ & 2 & $\begin{array}{c}11.0 \\
(11.5)\end{array}$ & $\begin{array}{c}14.5 \\
(16.0)\end{array}$ & $\begin{array}{l}1(50 \%) \\
1(50 \%)\end{array}$ & $\begin{array}{l}1(50 \%) \\
1(50 \%)\end{array}$ & $\begin{array}{l}1(50 \%) \\
1(50 \%)\end{array}$ & $\begin{array}{l}1(50 \%) \\
1(50 \%)\end{array}$ \\
\hline $30-35$ & 4 & $\begin{array}{c}10.8 \\
(10.3)\end{array}$ & $\begin{array}{c}12.5 \\
(12.0)\end{array}$ & $\begin{array}{l}3(75 \%) \\
3(75 \%)\end{array}$ & $\begin{array}{l}1(25 \%) \\
1(25 \%)\end{array}$ & $\begin{array}{l}2(50 \%) \\
1(25 \%)\end{array}$ & $\begin{array}{l}2(50 \%) \\
3(75 \%)\end{array}$ \\
\hline $35-40$ & 12 & $\begin{array}{c}12.4 \\
(12.1)\end{array}$ & $\begin{array}{c}13.2 \\
(13.1)\end{array}$ & $\begin{array}{l}7(58 \%) \\
7(58 \%)\end{array}$ & $\begin{array}{l}5(42 \%) \\
5(42 \%)\end{array}$ & $\begin{array}{l}8(67 \%) \\
5(42 \%)\end{array}$ & $\begin{array}{l}4(33 \%) \\
7(58 \%)\end{array}$ \\
\hline
\end{tabular}

Table 6: Statistical Summary - Hypermetropia Cases Female: Right Eye and Left Eye

DISCUSSION: The study was conducted to find out if there is any significant relationship between refractive error (myopia and hypermetropia) and intra ocular pressure which could be one of the reasons for the development of glaucoma in future.

Similar studies were conducted separately by Klein BEK et al. (1992), ${ }^{3}$ Weigh LM et al (2001), ${ }^{4}$ Mitchell P et al (1999) ${ }^{5}$ and David R. et al in the year 1985. ${ }^{6}$ They also found that the adults have significant relations between IOP and refractive error or myopia.

Intraocular pressure testing was attempted in all age groups of children, by Quinn GE, Berlin JA, Young TL, Ziylan S, Stone RA in the year $1995,{ }^{13}$ but the test was more successful in older children. The mean IOP of $17.3 \mathrm{mmHg}$ in the right eye and $17.2 \mathrm{mmHg}$ in the left eye was recorded. These results indicate that IOP in children may be higher in myopic than nonmyopic eyes. In the present study also it was found that the most of the myopics have higher IOP as revealed in table no. 3 and table no. 4. Further, the studies conducted by Mitchell P, Hourihan F, Sandbach J, Wang JJ ${ }^{14}$ confirmed a strong relationship between myopia and glaucoma. Myopic subjects had a twofold to threefold increased risk of glaucoma compared with that of nonmyopic subjects. The risk was independent of other glaucoma risk factors and IOP.

In conclusion, the present studies reveal that the right eye myopic females with higher IOP in the age between 25 to 30 are prone to develop glaucoma in future. There is also a significant relation between mean IOP value and hypermetropia with respect to both right and left eye of females in the age group of 35 to 40.35 to 40 years with higher mean IOP value in myopic males is more vulnerable to develop glaucoma in future.

\section{BIBLIOGRAPHY:}

1. Saw SM; Katz J; Schein OD et al. Epidemiology of myopia: Epidemiol Rev.1996; 18:175- 87.

2. Pruett RC. Progressive myopia and intraocular pressure: what is the linkage? A literature review: Acta Ophthalmol Suppl. 1988; 185: 117-27.

3. Klein BEK; Klein R; Linton KL. Intraocular pressure in an American community, the Beaver Dam Eye Study: Invest Ophthalmol Vis Sci.1992; 33: 2224-8.

4. Weih LM; Mukesh BN; McCarty CA et al. Association of demographic, familial, medical, and ocular factors with intraocular pressure: Arch Ophthalmol. 2001; 119: 875-80.

5. Mitchell P; Hourihan F; Sandbach J et al. The relationship between glaucoma and myopia: Ophthalmology. 1999; 106: 2010-15.

6. David R; Zangwill LM; Tessler $\mathrm{Z}$ et al. The correlation between intraocular pressure and refractive status: Arch Ophthalmol.1985; 103:1812-15.

7. Lee A J; Saw S-M; Gazzard G; Cheng A; and Tan D T H. Intraocular pressure associations with refractive error and axial length in children: British J Ophthalmol. 2004; January; 88 (1): 5-7. 


\section{ORIGINAL ARTICLE}

8. Jensen H. Myopia progression in young school children and intraocular pressure: Doc Ophthalmol. 1992; 82(3): 249-55.

9. Ntim-Amponsah C. Contribution of Refractive Errors to Visual Impairment in Patients at KorleBu Teaching Hospital: Ghana Med J. 2007; June; 41(2): 68-71.

10. Ehrlich JR, Haseltine S, Shimmyo M. Evaluation of agreement between intraocular pressure measurements using Goldmann applanation tonometry and Goldmann correlated intraocular pressure by Reichert's ocular response analyser: Eye (Lond). 2010; 24: 1555 - 1560.

11. Amjad Akram, Amir Yaqub, Asad Jamal Dar, Fiaz. Pitfalls in Intraocular Pressure Measurement by Goldmann-Type Applanation Tonometers: Pak J Ophthalmol. 2009; 25 (4).

12. Grant WM. Fluorescein for Applanation Tonometry. More convenient and uniform application: Am J Ophthalmol. 1963; 55: 1252-3.

13. Quinn GE; Berlin JA; Young TL; Ziylan S; and Stone RA. Association of intraocular pressure and myopia in children: Ophthalmology. $1995 \mathrm{Feb}$; 102 (2):180-5.

14. Mitchell P; Hourihan F; Sandbach J; and Wang JJ. The relationship between glaucoma and myopia: the Blue Mountains Eye Study: Ophthalmology. 1999 Oct; 106 (10):2010-5.

\section{AUTHORS:}

1. Kavita Patil

2. Pranathi Kura

3. Shwetha Mangalesh

\section{PARTICULARS OF CONTRIBUTORS:}

1. Professor and HOD, Department of Ophthalmology, Raichur Institute of Medical Sciences.

2. Junior Resident, Department of Ophthalmology, Raichur Institute of Medical Sciences.

3. MBBS Student, Department of Ophthalmology, Raichur Institute of Medical Sciences.

\section{NAME ADDRESS EMAIL ID OF THE CORRESPONDING AUTHOR:}

Dr. Kavita Patil, H.No. 1-11-77(256), Beside Ganesh Temple, Nijalingappa Colony, Raichur - 584101.

E-mail: drpatilkavi@yahoo.co.in

Date of Submission: 02/01/2014. Date of Peer Review: 03/01/2014. Date of Acceptance: 16/01/2014. Date of Publishing: 04/02/2014. 